\title{
НЕМЕЦКАЯ ФИЛОСОФИЯ XVIII-XIX ВВ.: ЧЕТЫРЕ АСПЕКТА КЛАССИЧНОСТИ
}

\section{И.А. Филина}

Словосочетание «классическая немецкая философия» давно стало своеобразным и привычным трафаретом, и только редкие вопросы любознательных студентов заставляют вдаваться в пояснения феномена классичности. Действительно, почему не назвали классической французскую или английскую философию того же периода? Какая философия вообще достойна «звания» классической?

Вспомним происхождение самих терминов «классический» и «классики». Латинское «classicus» означает «образцовый». Сначала это слово обозначало того, кто принадлежал к высшему рангу из пяти цензовых категорий, на которые были разделены граждане Древнего Рима. В метафорическом смысле («элита») слово «классики» впервые было применено Цицероном, а в отношении литературы-Авлом Геллием (II в.). Со временем гуманисты Возрождения, для которых «образцами» были все античные писатели, философы, живописцы, скульпторы, архитекторы, тоже назвали их классиками.

Употребление понятий «классический» и «классика» распространилось постепенно в значении лучшего, совершенного, образцового, первого в своем роде. Классиками стали называть всех выдающихся мастеров литературы и искусства, творчество которых имело исключительную ценность не только для национальной, но и для мировой культуры. Широкому толкованию «классического» стали придавать также и дополнительный смысловой оттенок- показателъный, характерный, типовой. (Например, классический французский роман или классическая венская оперетта.) Часто определение «классический» выступает синонимом зрелого, завершенного: классическая

Актуальні проблеми духовності:

зб. наук. праць / Ред.: Я.В. Шрамко

Вип. 10. - Кривий Ріг, 2009, 156-?? 
механика, классическая архитектура и т. п. Наконец, термин «классический» вмещает в себя значение основополагающего, программного: классический танец, классическое образование.

Попробуем рассмотреть немецкую философию XVIII- первой половины XIX века в аспектах классичности в следующем порядке:

1) как явление типичное и характерное именно для Германии;

2) как зрелую и завершенную философию рационализма;

3) как лучший, совершенный и образцовъй философский продукт;

4) как программный, основополагающий в плане философской образованности компонент.

Карта Германии XVIII века представляла собой довольно пеструю картину: страна была раздроблена на более чем 360 королевств, курфюрств, баронств, графств, княжеств и вольных городов. Их политическая самостоятельность была подчас иллюзорной, повсюду царили междоусобицы и неразбериха. Для объединения страны отсутствовали какие-либо экономические и правовые предпосылки: ни скольконибудь значительной торговли с другими странами, ни свободы печати, ни общественного мнения, ни средств воздействия на сознание масс - словом, ничего такого, что хотя бы отдаленно походило на социальный мир по другую сторону Рейна. Именно оттуда, из Франции долетал освежающий ветер свободы, в то время как в самой Германии царила «скотская неподвижность» (Г. Гейне). Французская революция, словно молния, ударила в немецкое царство тяжелой и сплошной дремоты, вызвав волну общего энтузиазма, который, казалось бы, смыл уныние и безнадежность: в винных погребках запели «Марсельезу», посылались приветственные послания Национальному собранию Франции, поэты прославляли французский народ.

Однако в то время как юноши Франции сражались на баррикадах за идеалы свободы, справедливости, равенства и прогресса, их ровесники в Германии были лишены возможности активных действий. Поэтому новейшие идеалы Просвещения воплощались немецкими интеллектуалами преимущественно в творениях духа. Тоску по деятельности немцы изливали в стихах, романах, сонниках, дневниках, на страницах которых они предавались мечтам, ища спасения в мистике, в самоанализе душевных переживаний и в сладостных романтических грезах. В созданных поэтическим воображением мирах возводились 
воздушные замки, клеймились деспоты, свершались неслыханные мятежи и рушились царства. И именно в таких мирах «настоящие сыны Германии» героически и самоотверженно боролись за свободу, за объединение немецких земель, против всех тронов и тиранов.

Таким образом, бурлящая энергия социального протеста образованных умов в Германии, не найдя естественного выхода, сконцентрировалась в сфере духа.

Французам и русским досталась земля, Британец владеет морем,

А мы - воздушным царством мечты-

Там наш престиж бесспорен...

напишет Генрих Гейне.

Ситуация, что сложилась в «воздушном царстве мечты», объясняет формирование романтизма не только как духа эпохи, но и как стиля мышления, который распространился на литературу, музыку, искусство и философию.

Благодаря романтизму в духовной культуре, в том числе и в философии, довольно скоро вызревает и утверждается приниип историзма. Отвергая повседневность как нечто серое и прозаическое, романтики жаждали чего-то необычного, их волновали далекие страны, экзотические народы, загадочные эпохи прошлого, народные легенды и мифы. Более того, интерес к прошлому подпитывается стремлением немцев ощутить определенную значимость себя как народа в условиях раздробленности страны. Интеллектуальные поиски оснований для национальной гордости весьма быстро переключают интересы немцев с далекой экзотики на собственное историческое прошлое. Усиленное внимание проявляется к народным легендам, поэзии, живописи, к реальной истории и языкам немецких народов (баварцев, саксонцев, пруссов).

Углубление в прошлое совершается ради осмысления настоящего, в поисках исходных причин разобщенности народа и раздробленности страны. На этой же волне историзма проявляется желание национального прогресса, дальнейшего развития. Отсюда вполне закономерным результатом является и идея национально-культурного единения, завоевывающая огромную популярность. Если такие ценности Просвещения, как свобода, равенство, прогресс, проникшие в культурный дух Германии XVIII века, были популярными во всей образованной Европе, то идея единства имеет чисто немецкое происхождение. Именно эта 
идея обусловит глобальное «системосозидание» в сфере философии. Таким образом, романтизм как литературно-философское направление Германии 90-х годов XVIII века дал ощутимые интеллектуальные плоды: идеи историзма и единства.

Наглядной реализацией этих плодов может служить сочинение Иоганна Готфрида Гердера «Идеи к философии истории человечества», где автор излагает концепцию эволюции природы и общества, начиная с истории планеты и ее места в системе Вселенной. Гердер объясняет прогресс как нескончаемую цепь исторических изменений, причем речь идет о прогрессе, главным образом, человека и культуры. Самой ценной является мысль Гердера о том, что именно история помогает мысленно охватить прошлое и настоящее в их единстве. И именно историю он называет настоящей «воспитательницей» человечества, а смысл прогресса состоит, по его мнению, в воплощении гуманности, справедливости и «естественного света» разума.

Подтверждает признание ключевых ценностей своего времени и Фридрих Шлегель, выдвинувший идею создания универсальной новой культуры, которая объединяла бы науку, искусство, историю, поэзию и философию. Основанием для этой универсальной культуры должна была стать всеобщая духовная эволющия, главная роль в которой отводилась немецкой поэзии и философии.

В свою очередь, романтический стиль мышления существенно подпитывался завоеваниями самой философской мысли. Когда в Париже под натиском повстанцев скрипели тяжелые ворота Бастилии, в Берлине, Кенигсберге и Йене скрипели перья - в Германии осуществлялась великая «интеллектуальная революция», начало которой обычно связывают с именем выдающегося философа Иммануила Канта. Именно Кант перевернул традиционное представление в философии, согласно которому субъект (человек) всегда подчинен объекту (природе, миру), находится в зависимости от него. По мнению Канта, предметом философии должно быть не изучение самих по себе вещей (природы, мира, человека), а исследование познавательной деятельности, установление законов человеческого мышления. Своеобразным центром у Канта является мыслящий субъект, который, познавая предметы, продуцирует, порождает знание о них. Таким образом, главное - это деятельность разума, его активность и конструктивность.

Следствием такой позиции явилось возвеличивание роли свободного разума, творческого духа вообще. Теоретиками романтизма была хорошо усвоена мысль Канта о том, что гений не подчиняется правилам, а сам их создает. Все романтики страстно защищают творческую 
свободу художника, его фантазию, беспредельность мечты, полагая, что истинная свобода возможна только в сфере духа, а реальный мир никогда не узнает свободы - он слишком громоздок и несовершенен.

В отношении понимания самого человеческого разума стоит напомнить следующее. Античность открывает разум как отличительную черту человека от животных. Средневековье считает разум помощником души при выборе между добром и злом. В Новое время разум понимается как инструмент (органон) познания, как сила, преобразующая природу. Эпоха Просвещения надеется на массовый разум (образованность), как на гарант общественного и культурного прогресса. В XVIII веке окончательно оформляется культ разума, который в немецкой философии перерастает в культ свободного разума.

Именно культ свободного разума позволяет немцам стремительно осваивать всю сферу духовности, все «воздушное царство мечты», возводя умозрительные миры в литературе и масштабные философские системы. В истории Германии вряд ли найдется более щедрое на таланты и гении время, чем это. Именно тогда Германия заслуживает название «страны поэтов и мыслителей». Глубокий след оставили в поэзии и литературе Шиллер, Гете, Виланд, Гельдерлин, Новалис, Шамиссо, Гофман, Клейст, Гейне, братья Гримм; в музыке-Моцарт, Гайдн, Бетховен, Вебер, Шуберт; в философии, эстетике и социальной публицистике - Кант, Гердер, Фихте, Шеллинг, Гегель, братья Шлегели, Форстер, Фейербах и другие.

Философы, пожалуй, наиболее наглядно демонстрируют в своих концепциях свободу разума, исследуют его конструктивистские возможности, «монтируют» впечатляющие рациональные системы. Философия данного периода является действительно классической как явление типичное, показательное и характерное именно для Германии. Эту философию характеризует:

1) глобализм, тотальность осмысления бытия, мира, природы, общества (как следствие беспредельной свободы разума и как следствие стремления к единству страны, нации, культуры);

2) чисто немецкий «порядок» (Ordnung) мышления как особый способ организации философских систем, а именно: выведение системы из единого принципа и возвращение к нему после развертывания системы, четкие контуры самой системы, логическая упорядоченность положений, строгая концептуальность;

3) обязательное «объяснение» с историей философской мысли, сра- 
внение новых философских систем с предыдущими (как следствие всеобщего культурного «историзма»). Переключение, не без помощи Канта, на онтологию субъекта привело к анализу всего разнообразия культурно-исторических форм различных субъектов - отдельных мыслителей, наций, человечества, а также всевозможных форм развертывания субъектов. XIX век стал «веком истории»: истории всеобей, истории литературы, искусства, права, религии, философии, истории языков, истории хозяйства и т. д.

Немецкая философия XVIII века выступает как классическая и в другом своем аспекте-в качестве зрелой и завершенной философии рационализма, начало которой обычно связывают с именами Парменида и Аристотеля. При этом особое внимание приобретает проблема исчерпания парменидовской версии бытия.

Как известно, философский рационализм исходит из признания разума основой познания. Еще Парменид различает знание «по истине», достигнутое посредством разума, и знание «по мнению», приобретенное посредством чувственного восприятия. Именно в разуме он усматривает критерий истины. Продукты деятельности разума-это понятия, категории, законы, в которых отражается сущность вещей и процессов. Ища эту сущность как истину, наука и философия почти всегда функционально совпадали. А точнее, философия развивалась по парадигме науки, прежде всего в Новое время и в эпоху Просвещения, когда связь философии с естествознанием была особенно отчетливой. В укрепление авторитета разума внесли свой вклад Декарт, Лейбниц, Кант, Гегель и другие философы.

Истоком рационалистической традиции служит парменидовское понятие «бытие» в качестве силы абсолютной мысли, которая удерживает мир от опрокидывания в хаос, обеспечивая ему надежность и стабильность. Бытие характеризуется Парменидом как нечто $e \partial u$ ное, неподвижное, устойчивое и вечное, пребывающее за миром чувственных вещей. Именно эта парменидовская версия бытия обусловила главную рационалистическую методологию: выводить все изменяющееся из неизменного, многое - из единого, существование - из сущности. Философы-рационалисты описывали не столько процесс, сколько результат.

Рационалистическое философствование сводилось к оттачиванию приемов и методов описания порядка, устойчивых связей, конечных форм, закономерных отношений, то есть всего того, что можно выра- 
зить через понятия, законы и категории (фиксированную продукцию разума). Поэтому в философии рационализма преобладающими стали логические формы мышления, а отсюда, в свою очередь, возникли неизбежные требования системности изложения, соблюдения строгой логической последовательности, четкой постановки цели, наличия исходного принципа философствования и обязательного возвращения к нему после развертывания философской системы и т.д. В плане исполнения всех этих моментов немецкие философы (со своим «Ordnung'oм» мышления) преуспели как никто другой!

Гегелевская философская система воистину может считаться образцом всего европейского рационализма. У него абсолютная идея объявляется началом и сущностью мира, а процесс познания равнозначен самопознанию разума, который постигает в мире свое собственное содержание. Развитие объективного мира предстает как чисто логический, рациональный процесс. Гегель по праву занимает вершину «диалектики понятий», поскольку «впервые представил весь природный, исторический и духовный мир в виде процесса» (Энгельс). Гегель не просто развил, но и «обогатил историзмом» парменидовскую традицию рационализма. Начиная с Аристотеля, мечтой всех философоврационалистов было: охватить все многообразие мира «сеткой понятий», то есть выразитъ существование через сущностъ. Гегель воплотил эту мечту, создав систему гибких и текучих понятий и законов («снятие», отрицание отрицания, форма и содержание, возможность и действительность и т. д.).

Таким образом, сущность была найдена и выражена наилучшим способом из всех возможных в пределах рационализма. Двигаться дальше методами рационалистического познания было уже некуда. Классика, то есть рационалистическая философия, завершилась. Нечто подобное произошло в живописи, когда мастера достигли фотографической точности в изображении природы, батальных сцен, портретов. Качественным скачком явился уже постклассицизм, ориентированный на передачу не форм, а чувств и настроений автора средствами композиционных и цветовых решений. Началась эпоха импрессионизма, абстракционизма, кубизма...

Ситуация в философии наилучшим образом была отражена Гете:

Суха теория, мой друг,

А древо жизни пышно зеленеет.

Это надо понимать так: сущность-то вроде бы найдена и теоретически выражена, а существование продолжается во все новых фор- 
мах и бесконечном разнообразии. И это породило сомнение: возможно ли и стоит ли уповать на разум, ища всевозможные смыслы и сущности, когда чувства гораздо богаче и без них все равно не обойтись? Из этого сомнения в универсальности и силе разума вытекает со временем эпоха «критики разума». Отсюда же изыскиваются аргументы в необходимости замены парменидовской концепции бытия другой, более мобильной, процессуальной версией. В свое время концепция Парменида получила предпочтение потому, что выглядела более стабильной и обнадеживающей по сравнению с гераклитовской «все течет».

Немецкая философия оказалась на этом концептуальном «разломе» миропонимания. Она как бы вновь выходит на гераклитовские позиции в понимании бытия как вечного изменения, процесса, движения. Немецкие мыслители стремятся охватить мир не только в его целостности, но и в его истории и восхождении.

Востребование гераклитовской версии бытия как становления было предопределено исчерпанностью рационалистической установки на постижение бытия как чего-то сущностного, неизменного, субстанционального, объективно-реального. К тому же своеобразный культ разума, его активность, свобода, познавательная динамика, в свою очередъ, подталкивали к пониманию бытия не как «результата», а как «nроцесса». Гегель провозглашает бытие равнозначным становлению, делает решительный шаг в сторону понимания бытия как процесса, но, сделав его, дальше идти не отваживается. Его диалектика понятий (как метод) вполне годится для нового взгляда на бытие, но Гегель сделал себя заложником не метода, а системы, отдав дань прежней рационалистической традиции (единому принципу, логицизму, системной завершенности).

Гораздо решительней оказывается Шеллинг. Он первым осознает ограниченность рационалистической философии, считая что «свободный разум не должен иметь логических оков». Он первым отказывается от «упорядочивания в систему» философских позиций и положений, чем обрекает себя на непонимание со стороны своих современников. Философия для Шеллинга - это открытая система, это сама история философствования, отражающая бесконечное развертывание Абсолюта в мир. «С подачи» Шеллинга начинается время «критики разума», привлечения к познавательным процессам других, кроме разума, способностей человека - воли, интуиции, подсознания. Идеи Шеллинга так или иначе инициировали почти все последующие философские направления (экзистенциализм, «философию жизни», фрейдизм и т.д.). Именно Шеллинг оказался ключевой фигурой того осо- 
бого периода в развитии мировой философской мысли, который стал переходным от классического типа философствования к неклассическому.

Немецкая философия XVIII - первой половины XIX веков-это своего рода «последний аккорд» всей эпохи классицизма, вобравшей в себя все его основные черты. Она является действительно классической как явление типичное, показательное и характерное именно для Германии. Она есть зрелая и завершенная философия рационализма.

Немецкая философия является также лучшим и совершенным философским продуктом с точки зрения разработки диалектики - учения о всеобщей связи и развитии. Диалектика стала тем универсальным методом познания, поиски которого активно начались в эпоху Нового времени эмпириками и рационалистами. Эффективность и действенность категорий и законов диалектики многократно подтвердилась в различных сферах познания бытия.

Наконец, в силу выше изложенного, немецкую философию XVIII - первой половины XIX веков действительно можно считать классической в качестве программного компонента общей философской культуры. Никто не вправе называть себя зрелым философом, кто не окунался в «бездну» немецких Абсолютов, антиномий, императивов и трансценденций. И вообще, овладение диалектикой - настоятельная необходимость для любого образованного человека, поскольку она является своеобразной «азбукой» мышления, способом его организации и результативности. Диалектика - основа не только философской, но и общей культуры мышления. Таким образом, философия Германии XVIII- первой половины XIX веков является классической по всем основным параметрам классичности.

\section{1 Литература}

[1] Волков Г.Н. Сова Минервы. - М.: Молодая гвардия, 1985.

[2] Лазарев В.В. Шеллинг.-М.: Мысль, 1976.

[3] Филина И.А. Романтизм как дух эпохи и стиль мышления // Bceсвітня література і культура в навчальних закладах України.№ 6 . -2001 .

[4] Филина И.А. Шеллинг - классик, постмодернист и современник // Sententiae: наукові праці Спілки дослідників модерної філософiï. - III (1/2001). - Універсум-Вінниця, 2001. 